\title{
WHY DO FIRMS VOLUNTARILY ADOPT ENVIRONMENTAL MANAGEMENT SYSTEMS? THE CASE OF THE CZECH REPUBLIC
}

\author{
Eva Horváthová ${ }^{1}$ \\ ${ }^{1}$ Global Change Research Institute of the Czech Academy of Sciences, Department of the Human Dimensions \\ of Global Change, V Jircharich 6, Prague 1, 110 00, Czech Republic
}

Link to this article: https://doi.org/10.11118/actaun202068010157

Received: 9. 1. 2020, Accepted: 15. 1. 2020

To cite this article: HORVÁTHOVÁ EVA. 2020. Why Do Why Do Firms Voluntarily Adopt Environmental Management Systems? The Case of the Czech Republic. Acta Universitatis Agriculturae et Silviculturae Mendelianae Brunensis, 68(1): 157-168.

\begin{abstract}
We examine why firms voluntarily implement environmental management systems. Employing the ISO 14001 management system and using firm-level data for the Czech Republic, we find that environmental management systems are typically adopted by large firms and by those firms that initially pollute the environment more. These systems are more commonly implemented by firms operating in service industries. On the other hand, we find little support that the adoption of environmental management systems is influenced by the firm's financial performance and labor costs.
\end{abstract}

Keywords: environmental management systems, firms, logit

\section{INTRODUCTION}

Why do some firms become "green" and voluntarily adopt environmental management systems, why other firms not? Fiorino (2006) notes that the system of environmental regulation around the globe has changed significantly. While nearly no firms participated in environmental management systems (such as ISO 14001 by the International Organization of Standardization) in the 1990s, hundreds of thousands of firms participate in these systems nowadays. Therefore, many firms complement the central governmental type of regulation with more decentralized self-regulation. The "old" system e.g. command and control, was based on the notion that environmental regulation and firms' interests are in contradiction. To the contrary, Fiorino (2006) emphasizes that the new corporate-self regulation system of environmental regulation will allow firms more flexibility according to their actual performance, their differences and capabilities to meet certain environmental goals at different points of time.
Under the new system, the environmental responsibility of companies more commonly takes a form of corporate self-regulation built into a corporate business model. Since the "old" and the incoming corporate-self regulation systems will coexist together; it is essential to study the impact and the occurrence of the new approaches to environmental regulations. Corporate selfregulation is one of the new approaches to environmental regulation. It became more dominant during the 1990s (Fiorino, 2006) following the introduction of the British Standard 7750 in the early 1990s. Subsequently, the European Union started implementation of EMAS (Eco-Management and Audit Scheme) in 1993 and the International Organization for Standardization (ISO) propagated its Environmental management standard ISO 14001 in 1996. Voluntary adoption of environmental management systems (EMS) represents one of the types of corporate self-regulation which allows firms to exhibit their corporate responsibility. 
Many multinational corporations have adopted EMS because it provides guidelines for formulating corporate environmental policy and targets, implementing and monitoring their environmental goals (Morrow and Rodinelli, 2002). The number of firms implementing EMS increases each year all over the world (European Environmental Agency, 2014; Charlet, 2019). These systems are widely adopted by large multinational firms, too. For example, the Ford Motor Company adopted ISO 14001 in its manufacturing plants and requires EMS certification by all its suppliers and manufacturing facilities worldwide. General Motors, Daimler-Chrysler, Toyota, and IBM are among the corporations which have embraced EMS, too (Morrow and Rodinelli, 2002). Naturally, the question, which arises is "Why do some firms voluntary participate in these programs while others not?". The question has been studied extensively, but the answer is far from being conclusive. As Alberini and Segerson (2002) note, different research has led to different findings with a vast list of firms' characteristics as well as external influences e.g., regulatory pressure. The previous research has also largely focused on most developed countries.

Our research contributes to the existing literature in the following ways. First, we use an innovative way to measure the environmental performance of firms, which has not been applied to study the voluntary adoption of environmental management systems so far. The novel measure of environmental performance, as proposed by Horváthová (2012), suggest the normalization of the different pollutant emitted amount by the reporting threshold. This threshold is set by the dangerousness of pollutant to the population and the environment. Second, we examine the Czech Republic, i.e., one of the central European countries, which became an EU member in 2004. Bracke et al. (2008) emphasize that the previous studies largely focus on the United States' Environmental Protection Agency's (EPA) voluntary programs in the United States (see, for example, Arora and Cason, 1995, or Videras and Alberini, 2000) or on the ISO 14001 adoption in Japan. The adoption of ISO 14001 by Japanese firms is studied, for example, by Hibiki et al. (2003) or Nakamura et al. (2001). The research on the adoption of environmental management systems in Europe, and especially in Central and Eastern Europe, is scarce. To our best knowledge, Henriques and Sadorsky (2006) and Garcia et al. (2009) represent the only studies which study Central and Eastern Europe. They study factors that influence the decision to adopt environmental management practices by Hungarian manufacturing firms in 2003. Garcia et al. (2009) study the adoption of environmental management practices (the establishment of environmental plans and environmental departments) in the six Central and Eastern European countries during the 1990s'. They find that the adoption of environmental management practices is driven by enforcement activities, public disclosure of environmental performances of firms, export-orientation, and firm size. The scarcity of the research in this area is not surprising, as it requires to merge several large firm level datasets, i.e. the datasets covering financial statements of firms, their environmental characteristics and adoption of environmental standards. Third, our dataset also contains smaller firms, while a typical study in this body of literature focused on large, often international or global, firms. Given that the EMS adoption entails nonnegligible fixed costs, the determinants of EMS adoption can be different for smaller firms.

We find that larger and more polluting firms are more likely to adopt an environmental management system. We also find that the probability of EMS adoption is influenced by the industry in which the company operates. However, we find no impact stemming from labor costs and financial performance of firms.

\section{Voluntary Environmental Programs}

The approach to regulation of the environmental problems has been changing over the last decades. While the command and control approach worked well for regulation mainly large stationary sources of pollution, the market-based approach started to be implemented in the 1980s due to its better efficiency (Fiorino, 2006). During the 1990's another new approach to combating with environmental problems emerged. This approach involves voluntary participation in environmental regulation. Under this approach firms voluntary decrease their environmental impacts below the level required by law (Fiorino, 2006; Prakash and Potoski, 2012).

There are several forms of these voluntary approaches, e.g., unilateral commitments made by polluters, private agreements between polluters and pollutes, negotiated agreements between a public authority and industry and voluntary programmes developed by public authorities (Prakash and Potoski, 2012; Börkey et al., 1999; Brouhle et al., 2004; OECD, 2003). The use of voluntary approaches has spread dramatically since they were introduced at the beginning of 1990's. Some voluntary approaches state an explicit environmental goal, e.g., U.S. EPA's 33/50 and WasteWise, while others have less direct policy objectives such as enhancing innovation or increasing awareness of environmental issues, e.g., the EcoManagement and Auditing Scheme (EMAS) and ISO 14001. Arguments for the promotion of the use of voluntary incentives include mainly higher environmental effectiveness, economic efficiency, reductions in costs (in terms of monitoring as well as enforcement), increases in environmental awareness, and encouragement of innovation. 
An Environmental Management System (EMS) represents a type of a voluntary pro-environmental approach that firms around the globe can implement. Participation in voluntary environmental approaches is a manner to signal a firm's involvement in corporate social responsibility. The EMS is a set of processes and practices that enable an organization to decrease its environmental impact. The United States' Environmental Protection Agency (U.S. Environmental Protection Agency, 2013) defines EMS as "a set of processes and practices that enable an organization to reduce its environmental impacts and increase its operating efficiency."

There are several different types of EMS. Globally, the most common is ISO 14001 (environmental management standards published by the International Organization of Standardization ISO). At the European level, firms often opt for the Eco-Management and Audit Scheme (EMAS). Besides these two widespread international standards (EMAS and ISO), there are many other standards at the country level such as the British Standard 7750 or the programs developed by the US Environmental Protection Agency such as Energy Star, 33/50, Green Lights. In the Czech Republic, ISO 14001 and EMAS are particularly used. We discuss and compare the ISO 14001 and EMAS standards below because they represent the most common standards by far.

\section{ISO 14000}

The ISO 14000 represents the international standard for the EMS published by the International Organization for Standardization (ISO). The ISO 14000 includes particularly the ISO 14001 standard, which represents the core set of standards for designing and implementing an efficient environmental management system. Other standards included are, for example, ISO 14004 (Environmental management systems - general guidelines on principles, systems and supporting techniques), 14020-14025 (Environmental labels and declarations), ISO 14031 (Environmental performance evaluation), 14040-14049 (Life Cycle Assessment) or ISO 14064 (Measuring, quantifying, and reducing Greenhouse Gas emissions). The original ISO 14001, which was in operation since 1996, was upgraded in 2004 with the new ISO 14001/2004 standard. A new revisited version of ISO 14001 is expected in 2015 to respond to the latest trends (ISO, 2014). Fig. 1 depicts the development of a number of ISO 14001 registered companies worldwide. We observe an enormous increase during the last two decades from nearly 0 to more than 300,000 firms certified by ISO.

According to the European Environmental Agency (2014), there were less than 20 thousands ISO 14001 registered organizations and sites in 2001 in the European Union while this number increased dramatically to over than 80 thousands in 2009.

\section{EMAS}

The EU Eco-Management and Audit Scheme (EMAS) has been introduced by the European Union council regulation No.1836/93, requiring an implementation in all European Union Member States (EU EMAS, 2014). EMAS represents a management tool for companies and other organizations to evaluate, report and improve their environmental performance. Initially, it was (the first version, EMAS I, was in operation since 1995) restricted to the industrial sector. In 2001, the scheme has been opened to all economic sectors including public and private services (EMAS II). In 2009, the EMAS Regulation was revised for the second time (EMAS III, Regulation (EC) No 1221/2009). Importantly, it has been opened to the organizations located both inside and outside EU, the European Economic Area and accession countries (EMAS Global).

The ISO 14001 Environmental Management System requirements are an integral part of EMAS. However, the EMAS takes into account additional elements to support organizations that continuously improve their environmental performance. While the EMAS and ISO 14001 share the identical

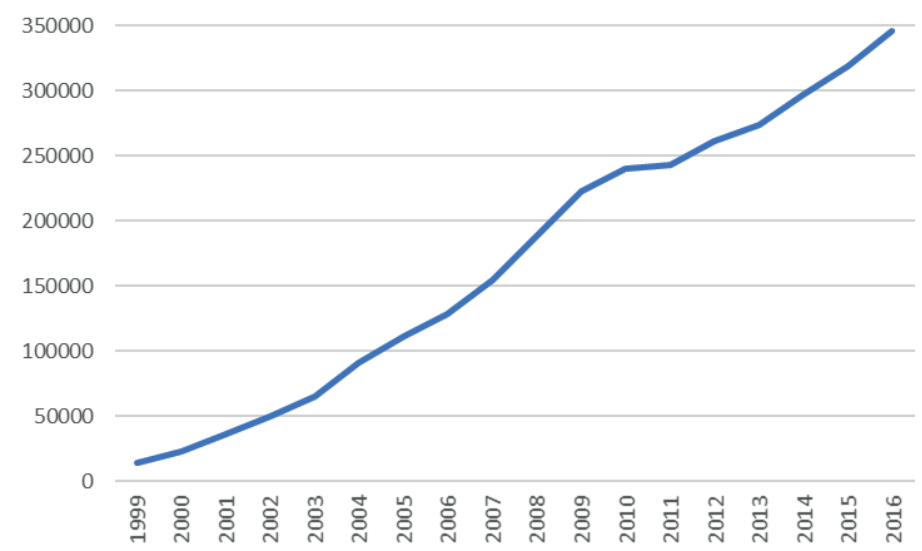

1: Total number of ISO 14001 registered organizations worldwide Source: Charlet, 2019 


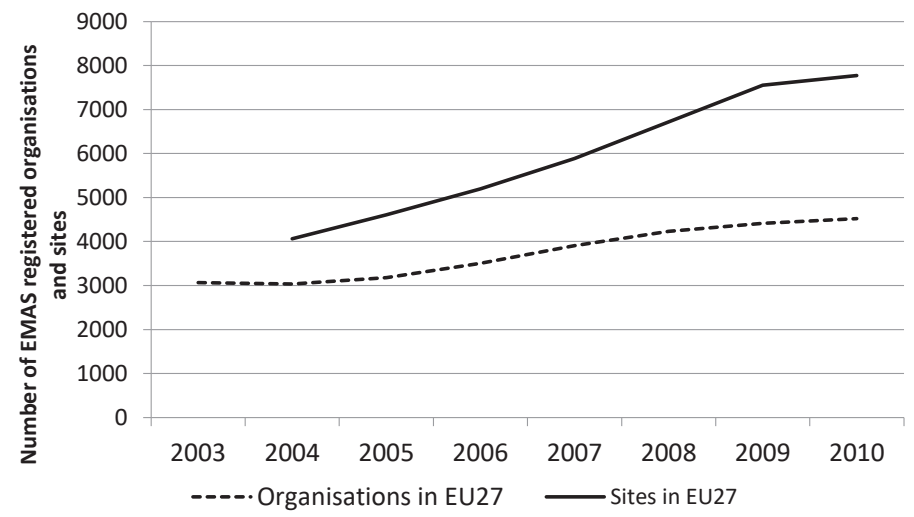

2: Number of EMAS certified organizations in the EU

Source: www.eea.europa.eu

Note: A site is a production facility of an organization, the smallest entity to be considered for registration.

objective (to provide sound environmental management) they differ in a number of ways, e.g. the legal basis (EMAS is under legal basis, while ISO 14001 is under the private law), the role of auditor (EMAS requires the independence of the auditor, while ISO only recommends the independence of the auditor), the external verification (EMAS is accredited through external environmental verifiers while ISO without external verification), improvement (EMAS requires annual improvement of environmental performance while ISO requires periodical improvement but without a defined frequency). We refer the reader to the EU EMAS website (EU EMAS, 2014), which provides further details regarding the differences between ISO 14001 and EMAS.

At the beginning of the $21^{\text {st }}$ century, there have been only about 3,000 EMAS registered organizations in the EU. This number slowly increased to about 4,500 registered companies in 2010 (see Fig. 2). Comparing the number of companies certified under ISO 14001 and EMAS in the EU countries, there are more than ten times more organizations registered under ISO 14001 than under EMAS standards (European Environmental Agency, 2014). According to the European Environmental Agency (2014), there are two reasons behind this difference. First, a process to be accredited by the EMAS is stricter and second, unlike the EMAS the ISO 14001 has unequivocally a global scope.

\section{Literature Review}

There is extensive evidence on the determinants of corporate participation in the voluntary environmental management programs. Although many studies suggest that the probability of EMS adoption increases with the firm size and product visibility, Alberini and Segerson (2002) note that it is far from easy to assess the impact of the firm size because practically all studied firms have been large so far.
The majority of studies examine ISO 14001 certification adoption e.g. Nakamura et al. (2001); Hibiki et al. (2003), Potoski and Prakash (2005) and the US Environmental Protection Agency programs e.g. Arora and Cason (1995 and 1996), DeCanio and Watkins (1998), Khanna and Damon (1999), Videras and Alberini (2000). We provide a brief summary of studies on EMS adoption below. Since ISO 14001 is the most widespread international environmental management system, the adoption of this system has been worldwide studied the most extensively.

\section{Research Examining the ISO 14001 Adoption}

Potoski and Prakash (2005) study US firms and find that government inspections and more stringent pollution regulations encourage firms to adopt ISO 14001. In addition, the facilities with moderate compliance records and the facilities operating in areas with more educated residents are more likely to adopt ISO 14001. This study examines particularly environmental management programs designed by the US Environmental Protection Agency.

The adoption of ISO 14001 certification has also been largely studied using the Japanese data. Hibiki et al. (2003) find that large firms, which are profitable, export-oriented and with higher R\&D expenditures are more likely to adopt the ISO 14001 certificate. In addition, they find that the probability of EMS adoption is influenced by the industry in which the firm operates, e.g. firms operating in manufacturing have a lower implementation rate than firms operating in other industries.

Nakamura et al. (2001) study the ISO 14001 certification adoption by large Japanese manufacturing firms. They conclude that the implementation rates are affected by firm size, the average age of firm employees, the export ratio and the debt ratio. Nishitani (2009) analyses the adoption of ISO 14001 by Japanese firms, too. Nishitani (2009) finds that the determinants of ISO 14001 adoption change over time depending on whether ISO was newly established or already in place for some time. 
Nishitani (2009) finds that initially, large firms with lower debt ratios were more likely to adopt the certification. In the next period, when most of the firms already adopted ISO 14001, the determinants of the adoption are somewhat different. The firms with higher export ratios, higher proportions of stock held by other corporations, larger size, and greater economic performance were more likely to certificate. In the last period, no systematic determinants of the certification adoption were found.

The adoption of ISO 14001 is also studied using Mexican data (Dasgupta et al., 2000; Blackman and Guerrero, 2012; Blackman, 2010). Dasgupta et al. (2000) find that firm-specific characteristics, e.g., company size and environmental training, play a significant role in the ISO 14001 adoption while stakeholder pressure does not. Blackman and Guerrero (2012) provide another study using Mexican data. They find that regulatory fines, which stand as a proxy for regulatory pressure and environmental performance, induce environmental certification. They also find that firms, which are exporting overseas, importing inputs and are relatively large, have higher probability of certification.

\section{Other Environmental Management Systems}

The American studies often examine the socalled 33/50 and Green Lights programs, which are the programs designed by the US Environmental Protection Agency. Arora and Cason (1995, 1996) study the US firms' participation in program 33/50. This voluntary program encourages firms to reduce releases and transfers of 17 toxic chemicals. They find that the firm size and industry effects are important determinants of firms' participation decisions. In addition, they find that public information and awareness play an important role in the adoption of the 33/50 program suggesting that the adoption of these programs provide a signaling value to the customers and the general public.

Khanna and Damon (1999) also analyze the 33/50 program and find that firms participate in the program if their expected gains are higher than the implementation costs of the program. They also test for communities' pressure, e.g., nongovernment and trade organizations. Videras and Alberini (2000) examine why firms participate in the EPA's three voluntary programs (33/50, Green Lights and WasteWise). They find that larger firms are more likely to participate in these programs and they explain it with better visibility of large firms. They conclude that public exposure is an important factor for participation. In the programs dealing with highly regulated pollutants, the firms, which emit more pollution are more likely to join the program. According to this result, there is a correction mechanism so that the firms, polluting the environment the most, try to reduce the environmental burden they produce. Next, the empirical results on participation in 33/50 program, e.g., Khanna and Damon (1999), Videras and Alberini (2000), support the idea suggested by Segerson and Miceli (1998) and Maxwell et al. (2000). According to Segerson and Miceli (1998) and Maxwell et al. (2000), firms adopt environmental management systems to pre-empt more stringent mandatory regulation or to soften enforcement of existing regulation.

While the research on the adoption of EPA's voluntary programs or ISO 14001 is comprehensive, the European program EMAS is so far studied less commonly. Bracke et al. (2008) seem to be the first study dealing with EMAS certification and studying European data. They find the following drivers of EMAS registration: financial structure, company size, profitability, average labor cost, type of firm's activities and headquarter location. Next, Blanco and Borsky (2013) study the EMAS implementation in all European Union countries from 1995 to 2010. Interestingly, they find that stricter environmental law reduces the number of EMAS certificates suggesting a trade-off between voluntary and mandatory environmental programs. They also find that better executive efficiency of a government increases the number of EMAS certification.

Vernon et al. (2009) investigate the benefits and costs of EMAS accreditation. Conducting both online questionnaire survey and interviews with organizations they identified the costs and benefits to organizations of EMAS registration, as well as the incentives and barriers faced by potential new registrants. According to this study, the most important reason for EMAS accreditation is the intention to improve resource and production efficiency (19\%), an internal management approach/ culture (18\%) and an improved reputation (15\%). The ambition to improve transparency with stakeholders and legislative compliance is also important for some organizations.

\section{MATERIALS AND METHODS}

\section{Data}

This section describes the data we use to assess firms' decision to implement EMS. The yearly data from 2004 to 2008 are used for all variables. The financial data are obtained from a commercial firm database CreditInfo. The database provides firms' full balance sheets and profit-loss statements for the vast majority of Czech companies (more than 2.3 million business subjects). The database also identifies the firm's industrial classification.

The data on EMS is collected using the publicly available database (see www.iso.cz). All data on EMS were double-checked by examining the websites of companies. Each company is examined whether it has a certification of both EMAS and ISO 14001 (and in which years the company has this certification). The vast majority of firms are certified with the ISO 14001. 
The environmental performance data in this study are obtained from the Integrated Register of Pollutant Emissions (freely available at www.irz.cz) which is a part of the European Pollutant Release and Transfer Register (EPRTR). The EPRTR provides publicly available access to environmental data from industrial facilities in the European Union Member States and Iceland, Liechtenstein, Norway, Serbia, and Switzerland. The EPRTR contains the data on an annual basis since 2007. In addition, it contains the data also for the years 2001 and 2004. The data for missing years (e.g., 2005 and 2006 to match our financial data) are available in the national registers (see www.irz.cz) and were collected under the same rules.

The EPRTR contains data on 93 pollutants releases to air, water and land as well as off-site transfers of waste and pollutants in wastewater from key pollutants including heavy metals, pesticides, greenhouse gases, and dioxins. Data collection and reporting is standardized across all pollutants in all countries. Therefore, datasets are comparable among all participating countries. Each pollutant is reported in this dataset if the emitted amount exceeds a reporting threshold. The reporting thresholds are set up concerning the main impact of the pollutants on human health and on the environment (the thresholds are set out by the European Commission in the Article 5 of the EPRTR Regulation). Each facility has to report to the register if it releases pollutants above the thresholds specified for each media (air, water, and land).
Merging the financial data with environmental performance dataset and with EMS data, we obtain a database, which contains 552 firms and 1177 observations. Although the financial database contains data on more than 2 million companies, the final database contains a smaller number of companies due to the lack of environmental data.

Tab. I presents the basic descriptive statistics. The majority of firms are not certified (neither EMAS nor ISO 14001). There are 167 observations with environmental certification, and there is only one firm which is EMAS certificated. As a result, our regression analysis focuses fully on the ISO 14001 implementation. The somewhat lower participation rate in total sample is in line with other similar research, e.g., Arora and Cason (1996), Bracke et al. (2008), Potoski and Prakash (2005). Bracke et al. (2008) analyze both EMAS and ISO 14001 and find a rather low ISO 14001 participation, too. They note, that, somewhat in contrast to theory, EMAS and ISO 14001 certificates are not considered as substitutes in practice. The majority of firms operates in agriculture, forestry, and fishing (NACE - A, 32\% of observations) and manufacturing (NACE - C, 32\% of observations). Only one observation is detected from NACE - N (Administrative and support service activities) and NACE - R (Arts, entertainment, and recreation). The dataset contains a wide range of companies of different size, ranging from the smallest companies (with assets less than 500 CZK) to companies with assets over 15 million CZK. Environmental performance is calculated as a weighted sum of pollutant emissions (details on calculations are included in section 5. Econometric Model).

I: Descriptive statistics

\begin{tabular}{lccccc}
\hline \multicolumn{1}{c}{ Variable } & No. of observation & Mean & Std. Dev. & Min. & Max. \\
\hline EMS (EMAS or ISO 14001) & 1,177 & 0.14 & 0.35 & 0 & 1 \\
EMAS & 1,177 & 0.00 & 0.06 & 0 & 1 \\
ISO 14001 & 1,177 & 0.14 & 0.35 & 0 & 1 \\
Assets (Ths. CZK) & 1,177 & 2,674 & 15,569 & 0.48 & 311,377 \\
Sales (Ths. CZK) & 1,177 & 760 & 10,026 & 0.00 & 211,026 \\
Wages/total assets & 1,038 & 0.15 & 0.23 & 0.00 & 4.90 \\
ROE & 1,174 & 0.14 & 1.04 & -21.60 & 10.15 \\
Environmental Performance & 1,177 & 250.5 & 1,969 & 0.00 & 49,333 \\
Industry - NACE - A & 1,177 & 0.32 & 0.47 & 0 & 1 \\
Industry - NACE - BCF & 1,177 & 0.34 & 0.47 & 0 & 1 \\
Industry - NACE - DE & 1,177 & 0.13 & 0.34 & 0 & 1 \\
Industry - NACE - GHI & 1,177 & 0.14 & 0.35 & 0 & 1 \\
Industry - NACE - JLMNRS & 1,177 & 0.07 & 0.26 & 0 & 1 \\
\hline
\end{tabular}

Note: NACE - A (Agriculture, forestry and fishing); NACE - B, C, F (Mining and quarrying, Manufacturing, Construction), NACE - D, E (Electricity, gas, steam and air conditioning supply, Water supply; sewerage; waste management and remediation activities), NACE - G, H, I (Wholesale and retail trade; repair of motor vehicles and motorcycles, Transporting and storage, Accommodation and food service activities) and NACE - J, L, M, N, R, S (Information and communication, Real estate activities, Professional, scientific and technical activities, Administrative and support service activities, Arts, entertainment and recreation, Other services activities). 


\section{Econometric Model}

This section describes the econometric model and the variables we use. We study which factors influence firms' decision to implement the EMS. We measure the firms' decision to adopt EMS as a binary variable EMS. The variable is defined as that it takes the value of one, if the firm has an EMS certification, zero otherwise. The firms have to undergo regular audits to maintain the EMS certification, or they can leave the system. The majority of firms maintain EMS for several years, but the abandoning the EMS after one year has also been detected. Given the binary nature of our dependent variable, we use the logistic regression to analyze the data.

A wide range of firms' financial and environmental characteristics are considered by previous literature as potential factors influencing firms' decision to implement the EMS. We motivate our empirical model by this previous literature to put some structure on our model. Therefore, we use the following independent variables capturing financial, labor, environmental and industry characteristics to study firms' decision to implement EMS: the firm size (measured as the log of total assets), environmental performance (the calculation is described below in detail), indebtedness (the ratio of debt to total assets), profitability (return on equity - ROE), labour cost and industry classification.

The following logit regression is estimated:

$$
\begin{aligned}
P\left(E M S_{i, t}=1\right)= & \Phi\left(a_{i}+b^{*} E P_{i, t-1}+c^{*} X_{i, t-1}+d^{*} D_{i, t-1}+\right. \\
& \left.+e^{*} F P_{i, t-1}+f^{*} L_{i, t-1}+g^{*} I_{i, t}\right)+e_{i, t}
\end{aligned}
$$

where $\mathrm{P}(\mathrm{EMS} \mathrm{i}, \mathrm{t}=1)$ is a binary variable indicating whether EMS has been adopted by i-th firm in time $t$. $E P_{i, t-1} \ldots$ is an environmental performance by i-th firm in time $\mathrm{t}-1$.

$X_{i, t-1} \ldots . .$. is firm size by i-th firm in time $t-1$.

$D_{i t-1}^{, t-1} \ldots .$. is indebtedness by $\mathrm{i}$-th firm in time $\mathrm{t}-1$.

$F P_{i, t-1}^{i,-\ldots}$ is profitability by $\mathrm{i}$-th firm in time $\mathrm{t}-1$.

$L_{i, t-1} \ldots . .$. is labour cost by $\mathrm{i}$-th firm in time $\mathrm{t}-1$.

$I_{i, t} \ldots \ldots \ldots$...is industry in which i-th firm operates.

It has been argued that larger firms are more likely to adopt EMS. The main argument for the adoption of EMS is greater firms' visibility to the public, a lower marginal abatement cost, and more extensive financial and personnel resources. Although the empirical evidence supports this supposition, e.g., Arora and Cason (1995 and 1996) and Khanna and Damond (1999), Alberini and Segerson (2002) emphasize that this evidence is still not conclusive.

Although the impact of environmental performance on the likelihood of EMS adoption has been widely investigated, Arora and Cason (1995), Khanna and Damond (1999) and Alberini and Segerson (2002) point out that the results vary across the studies. A majority of studies (e.g., Khanna, 2001) finds that poor environmental performance leads to higher participation rates in the EMS. In addition, Alberini and Segerson
(2002) emphasize that the difficulties in measuring environmental performance may influence the estimated effect of environmental performance on the EMS implementation.

We measure the environmental performance using the following EP indicator, in which the pollutant emitted amount is normalized according to the reporting threshold (see Horváthová, 2012, who proposed this normalization). The reporting thresholds are set up by the European Commission in the EPRTR Regulation concerning the main impact of the pollutants on human health and the environment. Since the harmfulness of each pollutant differs and the relative amount of each pollutant emitted also differs, total amounts cannot be generated as a simple sum. Instead, we first divide the emitted amount by the reporting threshold, if emissions are higher than the threshold.

The environmental performance for $i$-th firm in year $t$ is defined as:

$E P_{i, t}=\sum_{j=1}^{93} \frac{P_{i, j, t}}{R T_{j}}$

\section{if $P_{i, j, t} \geq R T_{j}$ and 0 otherwise}

where $E P_{i, t}^{j}$ is an environmental performance of a company, $P_{i, j, t}$ is an absolute amount of emission for pollutant $j, R T_{j}$ is a reporting threshold for pollutant $j$ and 93 is a number of pollutant tracked.

Next, we study the impact of firms' financial characteristics because the cost of EMS implementation is significant. Clausen et al. (2002) estimate EMAS implementation cost for the companies with more than 500 employees to range between $€ 85,000$ and $€ 322,000$. Once the EMS is adopted, its maintenance entails further costs. Another recent study (Vernon et al., 2009) finds the average costs of a typical EMAS organization around $€ 48,000$ for the first year and $€ 26,000$ annually for subsequent years.

The variable indebtedness (the ratio of debt to total assets) is used to assess whether less indebted firms have a higher probability of implementation. ROE is used to examine the effect of firms' profitability. The more profitable firms can use internal funds to cover the implementation costs and have better access to credit. We expect that firms with better financial position have a higher probability of EMS implementation since they are likely to sustain implementation costs.

We also test for the significance of labor cost (wages and salaries/total assets). This is motivated by Bracke et al. (2008), who argue that the higher labor costs may be paid due to more educated personnel and to those working in the less safe working environment.

Next, we control for the industry effects since other researchers find industry effects to be an important factor for the EMS adoption, e.g., Arora and Cason (1995, 1996), Hibiki et al. (2003), Videras 
and Alberini (2000). We use industry classification according to NACE codes. To reduce a number of explanatory variables, we group the NACE codes into the following groups: NACE - A (Agriculture, forestry and fishing); NACE - B, C, F (Mining and quarrying, Manufacturing, Construction), NACE - D, E (Electricity, gas, steam and air conditioning supply, Water supply; sewerage; waste management and remediation activities), NACE - G, H, I (Wholesale and retail trade; repair of motor vehicles and motorcycles, Transporting and storage, Accommodation and food service activities) and NACE - J, L, M, N, R, S (Information and communication, Real estate activities, Professional, scientific and technical activities, Administrative and support service activities, Arts, entertainment and recreation, Other services activities).

Since EMS adoption process typically takes several months (e.g., Hillary (1998) find that EMAS registration process takes between 6 to 24 months) the explanatory variables, except the industry dummies, are lagged by one year.

\section{RESULTS}

In this section, we provide the results on why the Czech firms adopt the EMS. Tab. II shows the regression results for various model specifications. We estimate the model by logistic regression in Tab. II and use probit as the robustness check (these results are available in the Appendix).

II: Why do firms adopt environmental management systems?

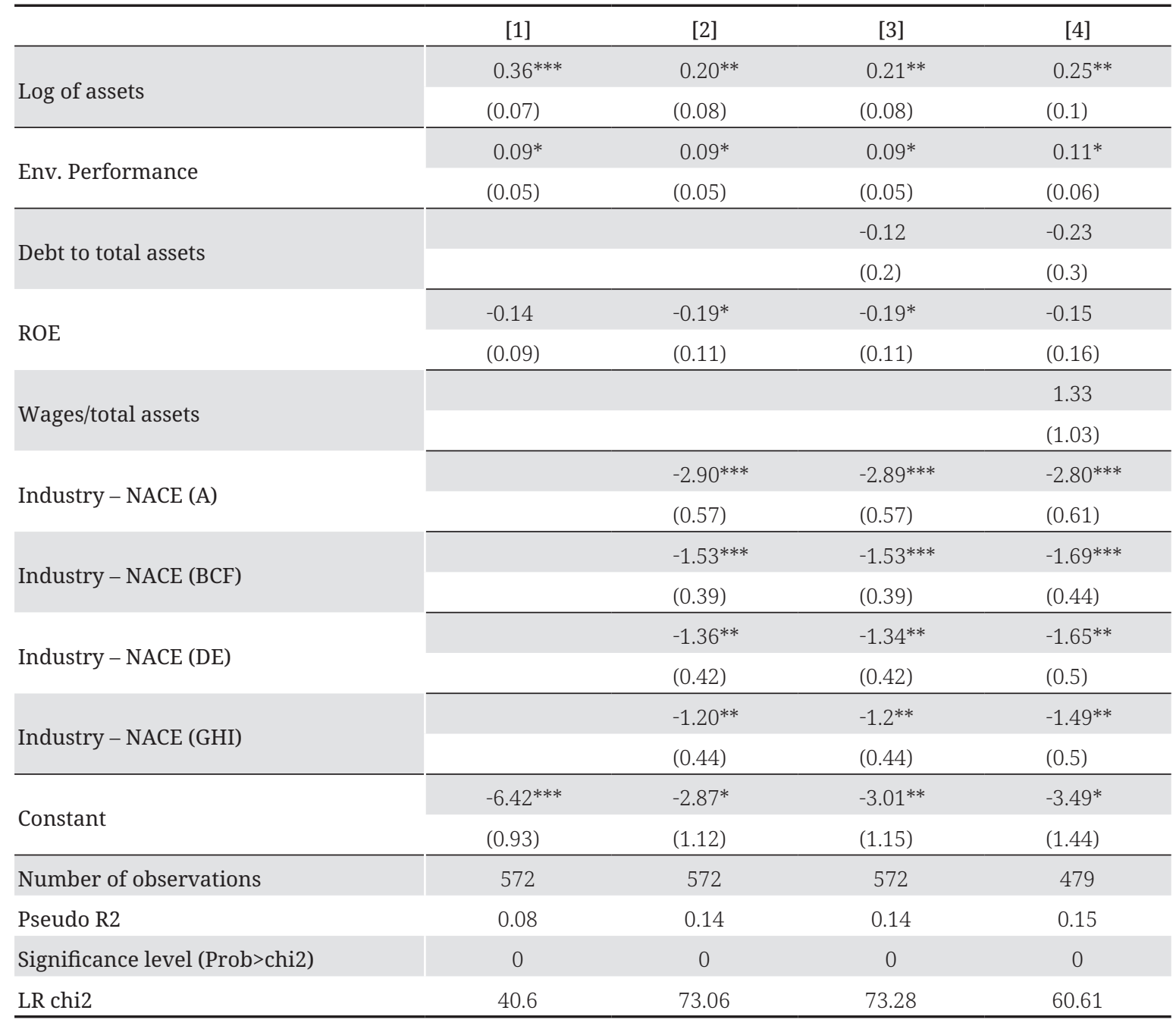

Note: Standard errors in parenthesis. ${ }^{* *} p<0.01,{ }^{* *} p<0.01,{ }^{*} p<0.1$. NACE - A (Agriculture, forestry and fishing); NACE - B, C, F (Mining and quarrying, Manufacturing, Construction), NACE - D, E (Electricity, gas, steam and air conditioning supply, Water supply; sewerage; waste management and remediation activities), NACE - G, H, I (Wholesale and retail trade; repair of motor vehicles and motorcycles, Transporting and storage, Accommodation and food service activities) and NACE - J, L, M, N, R, S (Information and communication, Real estate activities, Professional, scientific and technical activities, Administrative and support service activities, Arts, entertainment and recreation, Other services activities). The explanatory variables, except the industry dummies, lagged by one year. The regression coefficient on environmental performance divided by 1000. Logistic regression. Dependent variable: EMS (EMAS or ISO 14001). 
The results suggest that higher firm size is associated with the higher probability of EMS adoption. This result is in line with findings of other studies. For example, Arora and Cason (1995, 1996) studying US firms' participation in EPA's program 33/50 find similar results. Videras and Alberini (2000) examine participation in the three EPA's programs and find that larger firms have a systematically higher probability of participation in these programs, too. DeCanio and Watkins (1998), Hibiki et al. (2003), Nakamura et al. (2001), Dasgupta et al. (2000) also find the firm size to influence the decision to implement EMS.

Next, the likelihood of EMS adoption increases for more polluting companies. This finding can be due to that environmental certifications can be used as a tool to decrease firms' negative environmental impacts. This result corresponds to Blackman and Guerrero (2012), who find that environmental fines stimulate environmental certification in the subsequent three years. Similarly, Potoski and Prakash (2005) find that the adoption of ISO 14001 leads to improvements in firms' compliance with environmental law. Videras and Alberini (2000) find that the probability of participation in EPA's voluntary programs is higher for more polluting firms, too. Most studies but not all find that more polluting firms are more likely to participate in ISO 14001 (e.g. Potoski and Prakash (2005) and Darnall (2003)). Nevertheless, according to Alberini and Segerson (2002), the impact of environmental performance on the likelihood of EMS adoption vary across studies.

The probability of EMS adoption is influenced by the industry in which the company operates, too. Similarly, Arora and Cason (1995, 1996), Hibiki et al. (2003) find that operating industry influences the decision to implement the 33/50 program. Arora and Cason (1996) find that the probability of participation in the 33/50 program is higher in industries with higher exposure to consumers. Hibiki et al. (2003) find that firms operating in medicaments, metal, transportation equipment, precision machinery, and other manufacturing have less incentive for EMS adoption. Henriques and Sadorsky (1996) find that the probability of formulation of an environmental plan differs across industries, too. They find that firms in service sectors are less likely to formulate an environmental plan. To the contrary, we find that the firms operating in service industries implement EMS with higher probability.

On the other hand, the impact of firms' profitability, indebtedness and labor cost is not statistically significant. The finding that the probability of EMS adoption is not influenced by the labor cost does not correspond to the results of Bracke et al. (2008). Nevertheless, we measure the labor cost somewhat differently. Bracke et al. (2008) use the average cost of employees and average it over seven years period, while we measure the labor cost as wages plus salaries divided by total assets since we do not have data on the number of employees.

The results that financial performance and debt variables do not influence the probability of EMS implementation is consistent with previous research. Similarly, Arora and Cason (1995), Nakamura et al. (2001) and Videras and Alberini (2000) find that participation in the EMS programs is not affected with the financial health of the companies. On the other hand, Hibiki et al. (2003) find that firms with higher profitability are more likely to implement ISO 14001. However, Cole et al. (2006) find a negative influence of the financial variables on the probability of EMS implementation. In addition, the results of the previous research on the impact of debt variables are mixed, too. For example, Nakamura et al. (2001) and Cole et al. (2006) find that indebtedness negatively influences the EMS implementation decision while Arora and Cason (1995) and Hibiki et al. (2003) find the insignificant impact of debt ratio on EMS implementation decision.

To shed some light on the stability of the results both logit and probit regression is run. The results of logit regression are summarized in Tab. II. The results of probit regression are summarized in the Appendix. Tab. II and the Appendix indicate that the results of probit and logit regressions lead to the same conclusions.

\section{CONCLUSION}

We study why firms voluntarily invest in the adoption of environmental management systems (EMS). Most previous studies focus on the examining the adoption in developed countries. On the other hand, we examine the adoption of EMS in one of emerging market economies, the Czech Republic. Using the Czech data on both EMAS and ISO 14001 and merging them with comprehensive financial characteristics and environmental performance datasets, we find that the probability of EMS implementation increases with the firms' size. In addition, our results suggest that more polluting firms exhibit a higher probability of the EMS implementation. The probability of EMS adoption is also influenced by the industry in which the company operates. On the other hand, we fail to find that firms' financial characteristics matter for the adoption of these systems. 
Acknowledgements

We thank Roman Horváth, Lubomír Lízal, Bedřich Moldán and seminar participants at the Charles University and the University of Economics, Prague for helpful comments. This work was supported by the Czech Science Foundation (GACR), Grant No. 20-18261S.

\section{REFERENCES}

ALBERINI, A. and SERGENSON, K. 2002. Assessing Voluntary Programs to Improve Environmental Quality. Environmental and Resource Economics, 22(1): 157-184.

ARORA, S. and CASON, T. N. 1995. An experiment in voluntary environmental regulation: Participation in EPA's 3350 program. Journal of Environmental Economics and Management, 28(3): 271-286.

ARORA, S. and CASON, T. N. 1996. Why do firms volunteer to exceed environmental regulations?: Understanding participation in EPA's 33/50 program. Land Economics, 72(4): 413-432.

BLACKMAN, A. 2010. Alternative Pollution Control Policies in Developing Countries. Review of Environmental Economics and Policy, 4(2): 234-253.

BLACKMAN, A. and GUERRERO, S. 2012. What Drives Voluntary Eco-Certification in Mexico? Journal of Comparative Economics, 40(2): 256-268.

BLANCO, E. and BORSKY, S. 2013. Setting one voluntary standard in a heterogeneous Europe - EMAS, environmental taxes and institutional quality. Preliminary draft.

BŐRKEY, P., GLACHANT, M. and LÉVEQUE, F. 1999. Voluntary Approaches for Environmental Policy in OEDC Countries: An Assessment. CERNA, Centre d'économie industrielle.

BRACKE, R., VERBEKE, T. and DEJONCKHEERE, V. 2008. What Determines the Decision to Implement EMAS? A European Firm Level Study. Environmental and Resource Economics, 41(4): 499-518.

BROUHLE, K., GRIFFITHS, C. and WOLVERTON, A. 2004. The Use of Voluntary Approaches for Environmental Policymaking in the U.S. NCEE Working Paper Series. Working Paper No. 04-05. NCEE.

CLAUSEN, J., KEIL, M. and JUNGWIRTH, M. 2002. The state of EMAS in the EU: literature survey. Paper prepared for the EU Eco-Management and Audit Scheme: benefits and challenges of EMAS II, Brussels. Available at: http://ec.europa.eu/environment/emas/pdf/general/literature_study_020506_ en.pdf [Accessed: 2019, December 15].

COLE, M., ELLIOTT, R. and SHIMAMOTO, K. 2006. Globalization, firm-level characteristics and environmental management: a study of Japan. Ecological Economics, 59(3): 312-323.

DARNALL, N. 2003. Why Firms Certify to ISO 14001: An Institutional and Resource Based View. Academy of Management Proceedings 2003 One: A1-A6.

DASGUPTA, S., HETTIGE, H. and WHEELER, D. 2000. What improves environmental compliance? Evidence from Mexican industry. Journal of Environmental Economics and Management, 39(1): 3966.

DECANIO, S. J. and WATKINS, W. E. 1998. Investment in energy efficiency: Do the characteristics of firms matter? Review of Economics and Statistics, 80(1): 95-107.

EUROPEAN ENVIRONMENTALAGENCY.2014. Number of organisations with registered environmental management systems according to EMAS and ISO 14001. European Environmental Agency. [Online]. Available at: www.eea.europa.eu/data-and-maps/indicators/number-of-organisations-withregistered/assessment [Accessed: 2019, December 15].

EU EMAS. 2014. What is EMAS? European Commission. [Online]. Available at: http://ec.europa.eu/ environment/emas/index_en.htm [Accessed: 2019, December 15].

FIORINO, D. J. 2006. The new environmental regulation. The MIT Press.

GARCIA, J. D., BLUfFOSTONE, R. and STERN, T. 2009. Corporate Environmental Management in Transition Economies: The Case of Central and Eastern Europe. Finance a úvěr - Czech Journal of Economics and Finance, 59(5): 410-425.

HENRIQUES, I. and SADORSKY, P. 1996. The determinants of an environmentally responsible firm: an empirical approach. Journal of Environmental and Economics and Management, 30: 381-395.

HENRIQUES, I. and SADORSKY, P. 2006. The Adoption of Environmental Management Practices in a Transition Economy. Comparative Economic Studies, 48: 641-661.

HIBIKI, A., HIGASHI, M. and MATSUDA, A. 2003. Determinants of the Firm to Acquire ISO14001 Certificate and Market Valuation of the Certified Firm. Discussion Paper No. 03-06. Tokyo: Department of Social Engineering, Tokyo Institute of Technology.

HILLARY, R. 1998. Pan European Union assessment of EMAS implementation. European Environment, 8(6): 184-192. 
HORVÁTHOVÁ, E. 2012. The impact of environmental performance on firm performance: Short-term costs and long-term benefits? Ecological Economics, 84: 91-97.

CHARLET, L. 2019. The ISO survey. ISO. [Online]. Available at: https://www.iso.org/the-iso-survey.html [Accessed: 2019, December 15].

KHANNA, M. 2001. Non-mandatory approaches to environmental protection. Journal of Economic Surveys, 15(3): 291-324.

KHANNA, M. and DAMON, L. 1999. EPA's voluntary 33/50 Program: Impact on toxic releases and economic performance of firms. Journal of Environmental Economics and Management, 37: 1-25.

MAXWELL, J., LYON, T. and HACKETT, S. 2000. Self-Regulation and Social Welfare: The Political Economy of Corporate Environmentalism. Journal of Law and Economics, 43(2): 583-618.

MORROW, D. and RODINELLI, D. 2002. Adopting Corporate Environmental Management Systems: Motivations and Results of ISO 14001 and EMAS Certification. European Management Journal, 20(2): 159-171.

NAKAMURA, M., TAKAHASHI, T. and VERTINSKY, I. 2001. Why Japanese firms choose to certify: a study of managerial responses to environmental issues. Journal of Environmental Economics and Management, 42: 23-52.

NISHITANI, K. 2009. An empirical study of the initial adoption of ISO 14001 in Japanese manufacturing firms. Ecological Economics, 68(3): 669-679.

OECD 2003. Voluntary Approaches for Environmental Policy: Effectiveness, Efficiency, and Usage in Policy Mixes. Paris: OECD.

POTOSKI, M. and PRAKASH, A. 2005. Green Clubs and Voluntary Governance: ISO 14001 and Firms' Regulatory Compliance. American Journal of Political Science, 49(2): 235-248.

PRAKASH, A. and POTOSKI, M. 2012. Voluntary Environmental Programs: A Comparative Perspective. Journal of Policy Analysis and Management, 31(1): 123-138.

SEGERSON, K. and MICELI, T. 1998. Voluntary Environmental Agreements: Good or Bad News for Environmental Protection? Journal of Environmental Economics and Management, 36(2): 109-130.

U.S. ENVIRONMENTAL PROTECTION AGENCY. 2013. Environmental Management Systems (EMS). U.S. Environmental Protection Agency. [Online]. Available at: https://www.epa.gov/ems [Accessed: 2019, December 15].

VERNON, J., PEACOCK, M., BELIN, A., GANZLEBEN, C. and CANDELL, M. 2009. Study on the Costs and Benefits of EMAS to Registered Organizations. Milieu Ltd and Risk and Policy Analysis Ltd for DG Environment of the European Commission. Study Contract No. 07.0307/2008/517800/ETU/G.2.

VIDERAS J. and ALBERINI, A. 2000. The appeal of voluntary environmental programs: which firms participate and why? Contemporary Economic Policy, 18(4): 449-461. 


\section{APPENDIX}

Appendix A: Probit regression. Dependent variable: EMS (EMAS or ISO 14001)

\begin{tabular}{|c|c|c|c|c|}
\hline & [1] & [2] & [3] & {$[4]$} \\
\hline \multirow{2}{*}{ Log of assets } & $0.21^{* * *}$ & $0.12^{* *}$ & $0.12^{* *}$ & $0.15^{* *}$ \\
\hline & $(0.04)$ & $(0.04)$ & $(0.04)$ & $(0.06)$ \\
\hline \multirow{2}{*}{ Env. Performance } & $0.05^{*}$ & $0.06^{*}$ & $0.06^{*}$ & $0.07^{*}$ \\
\hline & $(0.03)$ & $(0.03)$ & $(0.03)$ & $(0.04)$ \\
\hline \multirow{2}{*}{ Debt to total assets } & & & 0.06 & -0.14 \\
\hline & & & $(0.11)$ & $(0.17)$ \\
\hline \multirow{2}{*}{ ROE } & -0.08 & $-0.11^{*}$ & $-0.11^{*}$ & -0.08 \\
\hline & $(0.05)$ & $(0.09)$ & $(0.06)$ & $(0.09)$ \\
\hline \multirow{2}{*}{ Wages/total assets } & & & & 0.78 \\
\hline & & & & $(0.57)$ \\
\hline \multirow{2}{*}{ Industry - NACE (A) } & & $-1.56^{* * *}$ & $-1.55^{* * *}$ & $-1.52^{* * *}$ \\
\hline & & $(0.29)$ & $(0.29)$ & $(0.32)$ \\
\hline \multirow{2}{*}{ Industry - NACE (BCF) } & & $-0.91^{* * *}$ & $-0.91^{* * *}$ & $-1^{* * *}$ \\
\hline & & $(0.23)$ & $(0.23)$ & $(0.27)$ \\
\hline \multirow{2}{*}{ Industry - NACE (DE) } & & $-0.81^{* *}$ & $-0.80 * *$ & $-0.99 * *$ \\
\hline & & $(0.25)$ & $(0.25)$ & $(0.3)$ \\
\hline \multirow{2}{*}{ Industry - NACE (GHI) } & & $-0.73^{* *}$ & $-0.73^{* *}$ & $-0.89 * *$ \\
\hline & & $(0.26)$ & $(0.26)$ & $(0.3)$ \\
\hline \multirow{2}{*}{ Constant } & $-3.77^{* * *}$ & $-1.71^{* *}$ & $-1.78^{* *}$ & $-2.13^{*}$ \\
\hline & $(0.52)$ & $(0.65)$ & $(0.66)$ & $(0.84)$ \\
\hline Number of observations & 572 & 572 & 572 & 479 \\
\hline Pseudo R2 & 0.08 & 0.14 & 0.14 & 0.15 \\
\hline Significance level (Prob>chi2) & 0 & 0 & 0 & \\
\hline LR chi2 & 42.07 & 73.38 & 73.6 & 61.26 \\
\hline
\end{tabular}

Note: See Table II. 